Apidologie, 1988, 19 (3), 231-240

\title{
FACTORS AFFECTING THE ACCEPTANCE OF FOREIGN DRONES INTO HONEY BEE (APIS MELLIFERA L.) COLONIES
}

\author{
R.W. CURRIE and S.C. JAY \\ Department of Entomology, University of Manitoba, \\ Winnipeg, Manitoba, Canada, R3T 2N2
}

\begin{abstract}
SUMMARY
Studies on drone management could aid in honey bee breeding programs by improving the efficiency and quality of mating. In this study the effects of introducing foreign drones into honey bee colonies were examined. Marked drones were introduced into single story colonies in the afternoon, evening and on the following morning. The number of drones accepted was measured for five consecutive days after drones were introduced. Introduced drones were either, released into the hive after crawling through a wire screen or were confined within the colony overnight by placing a queen excluder between the bottom board of the hive and the bottom box. The number of drones that was accepted was significantly higher when the marked drones were confined in the colony overnight, using queen excluders. There was a significant interaction between the introduction technique used and time of day when drones were introduced. When introduced drones were confined in colonies with queen excluders, acceptance was higher if the drones were introduced in the afternoon than when they were introduced in the evening or on the following morning. However, if drones were not confined within the colony ( $i$. $e$. no excluders were used) acceptance was highest in the evenings.

The number of drones that was accepted varied with the number that was introduced. When 50 or 95 drones were introduced the mean number of drones that were accepted after five days was not significantly different. However, when 50 or more drones were introduced, acceptance after five days was significantly higher than when only 25 drones were introduced. Therefore, the number of drones accepted by a colony can be increased by confining the drones in the colony for about 18 hours after introduction and by introducing drones in the afternoon or evening rather in the morning. The number of drones accepted, however, cannot be increased when more than 50 drones are introduced per hive.
\end{abstract}

\section{INTRODUCTION}

Studies on drone management could aid in honey bee breeding programs by improving the efficiency and quality of mating (CURRIE, 1987). Sub-optimal rearing and storage conditions may reduce the competitive ability of drones in "natural " matings, and/or lower the quantity and quality of the drone's sperm and accessory gland secretions. Large numbers of drones are commonly introduced into colonies during studies of their longevity, mating behavior, orientation behavior or flight activity. However, very little is known about how 
colonies respond to foreign drones that are introduced into colonies or about the number of introduced drones that a colony will support. There is little difficulty in introducing foreign worker bees into colonies and packages, or in re-introducing large numbers of marked worker bees back into their parent colonies (JAY, 1969). Only five percent of marked workers are lost after one day. However, honey bees regulate the number of adult drones in the colony (FreE and Williams, 1975). Thus, when large numbers of marked drones are introduced into colonies, losses are high $(\sim 45 \%)$ and are highly variable under different environmental conditions, between different colonies and between colonies of different queen types (CURRIE and $J_{A Y}, 1988$ ). Variable or low rates of drone acceptance can cause problems when large numbers of drones, equal numbers of drones or both are required in experimental colonies.

Low acceptance of introduced drones occurs when inclement weather, before or during the time of introduction, prevents workers from foraging (CURRIE and JAY, 1988). Most losses of introduced drones (45\%) occur within the first 24 hours after introduction; only $14 \%$ are lost between the first to the fifth day after introduction. Although more drones are accepted by queenless colonies than queenright colonies, the survival rates of drones that are accepted by queenless colonies do not differ from the survival rates of drones in queenright colonies (CurRIE and JAY, 1988).

Foreign worker bees can be successfully introduced by lightly smoking the colony, releasing the bees on the floorboard at the back of the hive, spraying the bees with dilute sugar syrup or any combination of these methods $\left(\mathrm{J}_{\mathrm{AY}}\right.$, 1969). Additionally, workers can be introduced by allowing them to crawl through a queen excluder that is placed on the top of the hive (Nelson, 1985). Methods currently used to increase the rate of drone acceptance include : lightly smoking the colony and forcing the drones to crawl into the hive through a wire screen (CuRRIE, 1982), re-introducing any drones that are evicted (WITHERELL, 1972) and introducing drones into queenless colonies (e.g. CURRIE, 1982 ; Rowell et al., 1986).

The objectives of this study were to determine an upper limit for the number of foreign drones a colony will accept, to reduce the variability in acceptance between hives and to increase the number of foreign drones that a colony will accept.

\section{MATERIALS AND METHODS}

Drones were reared from seven colonies each of which contained a dark strain of queen which was enclosed in a single frame queen excluder within each colony. Young worker bees, worker brood and pollen supplements were continuously supplied to these colonies. After a period of two days the drone 
combs containing eggs were removed and placed between frames of worker brood within the colony. When the drone brood was capped it was transferred to another colony until the drone brood was ready to emerge. Then all of the adult bees that were on the frames were brushed off and the frames were transferred to an incubator which was kept at $30^{\circ} \mathrm{C}$. Drones that emerged in the incubator overnight were marked the following day. Newly emerged drones were marked on the thorax using model airplane dope (see, Harris, 1979). Groups of 50 marked drones were stored in cages, fed sugar syrup (1:1 sugar to water, by volume) and stored in an incubator at $30^{\circ} \mathrm{C}$ until they were prepared for the colonies.

At the beginning of each experiment, colony populations were equalized so that each colony contained six frames of worker bees and three frames of brood. Each colony was given similar amounts of stored honey and pollen. All experimental colonies consisted of single chamber Langstroth hives.

Six treatment combinations were performed. The standard introduction technique (no excluder) used by CURrIE and JAY (1988) was compared to a modified technique (excluder) in which queen excluders were used to prevent drones from leaving the hive. Each of the two different introduction techniques were used to introduce drones in the afternoon (at 14:00 h, C.S.T.), in the evening (at 21:00 h, C.S.T.) and on the following morning (at 07:00 h, C.S.T.).

With the no-excluder technique, wire screen with $8 \mathrm{~mm}$ squares (three squares to the inch) was placed between the brood chamber and an empty hive box. Marked drones were released onto the screen, the bees were gently smoked and the lids replaced on top of the empty boxes. When all of the drones had moved down through the screen and into the hive, the screen and the empty box were removed. The excluder technique differed from the no-excluder technique in that a queen excluder was placed between the bottom box and the bottom board of each hive. Excluders were put in place at the time of each introduction. The queen excluders were removed before the next period of drone flight began.

Equal numbers of drones were introduced into each hive within a trial but the number that was introduced varied between trials. The date of introduction and the numbers introduced per hive (in brackets) in each trial were 9 June, 1983 (18), 13 June, 1983 (63), 17 June, 1983 (37), 4 July, 1983 (100), 10 July, 1983 (25), 10 July, 1983 (50), 10 July, 1983 (95), 12 August 1984 (25), 12 August 1984 (50) and 12 August 1984 (95).

Each hive was carefully examined early in the morning, before drone flight and all marked drones were counted. The number of drones accepted in each hive was recorded for five consecutive days after the drones were introduced. The data were analyzed using a split-plot ANOVA. The introduction technique and time of introduction were the main plots and the number of drones accepted over time was the sub-plot (SNEDEcor and Cochran, 1980). Trials were used as blocks to control for the variation in acceptance between introduction dates. The experiments on $10 \mathrm{July,} 1983$ and on 12 August, 1984 were analyzed separately using a split-plot design with the number of drones introduced as a main-plot, to determine if variation in the number of drones introduced had an effect on the level of acceptance over time. The data were transformed to square roots $\pm 1 / 2$. However, all data are presented as untransformed means.

\section{RESULTS}

The acceptance of drones was higher when queen excluders were used than when no excluders were used $(\mathrm{P}<0.003)$ (Fig. 1). Acceptance was greater in the afternoon and evening than on the following morning $(\mathrm{P}<0.05)$ (Fig. 1). However, there was a significant interaction $(P<0.001)$ between the introduction technique used and the time of day when drones were introduced. When the excluder technique was used acceptance was highest in the afternoon, but when no excluder was used, the acceptance of introduced drones 


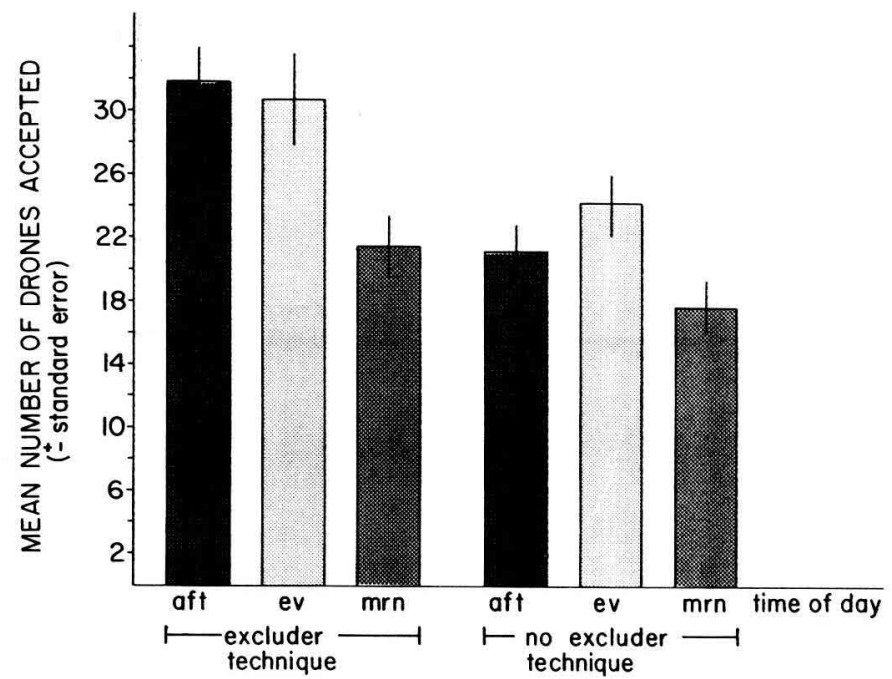

Fig. 1. - Mean number of drones accepted into colonies when two different techniques for introducing drones were used in the afternoon (aft), evening (ev) and following morning $(\mathrm{mrn})(100 \%$ acceptance mean $=55.8 \pm 3.88)$.

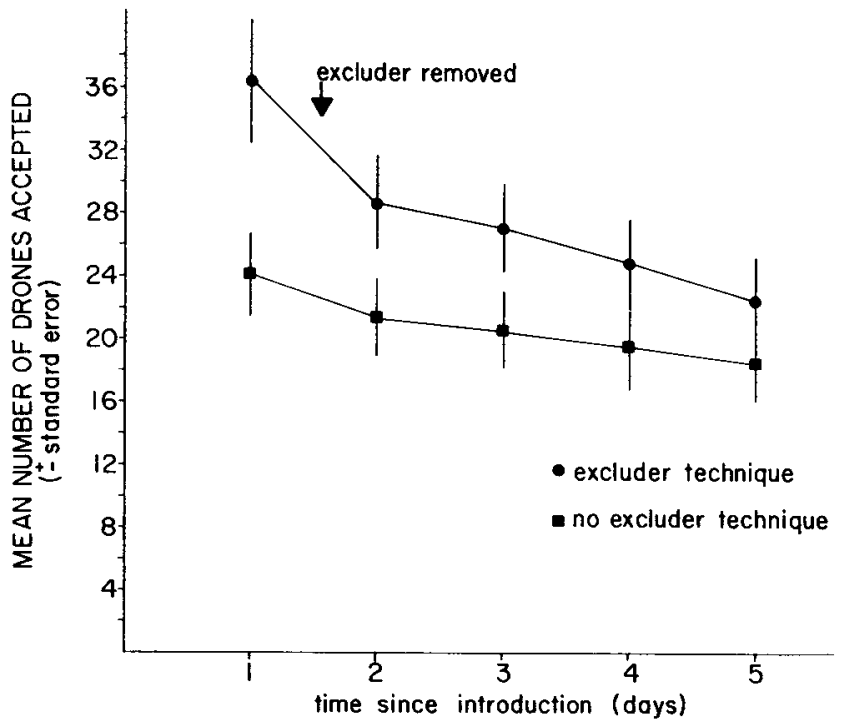

FIG. 2. - Mean number of drones accepted with two introduction techniques, during the first five days after drones were introduced $(100 \%$ acceptance mean $=55.8 \pm 3.88)$. 
was highest in the evening. Acceptance of drones was the lowest in the morning with both introduction techniques.

There was a significant $(P<0.05)$ reduction in the number of drones that were accepted during the first five days after drones were introduced (Fig. 2). The interaction between the introduction technique and the acceptance of drones over time was not significant $(\mathrm{P}>0.05)$.

The number of drones that were accepted varied with the number of drones that were introduced $(\mathrm{P}<0.005)$ (Fig. 3). Acceptance on the fifth day after introduction was significantly higher when 95 or 50 drones were introduced $(\mathrm{P}<0.05)$ than when only 25 drones were introduced. However, acceptance after five days did not differ $(P>0.05)$ if 50 or 95 drones were introduced (Fig. 3). The acceptance of drones was significantly higher $(P<0.05)$ on the first day after introduction (before removal of the queen excluders) than on the following four days.

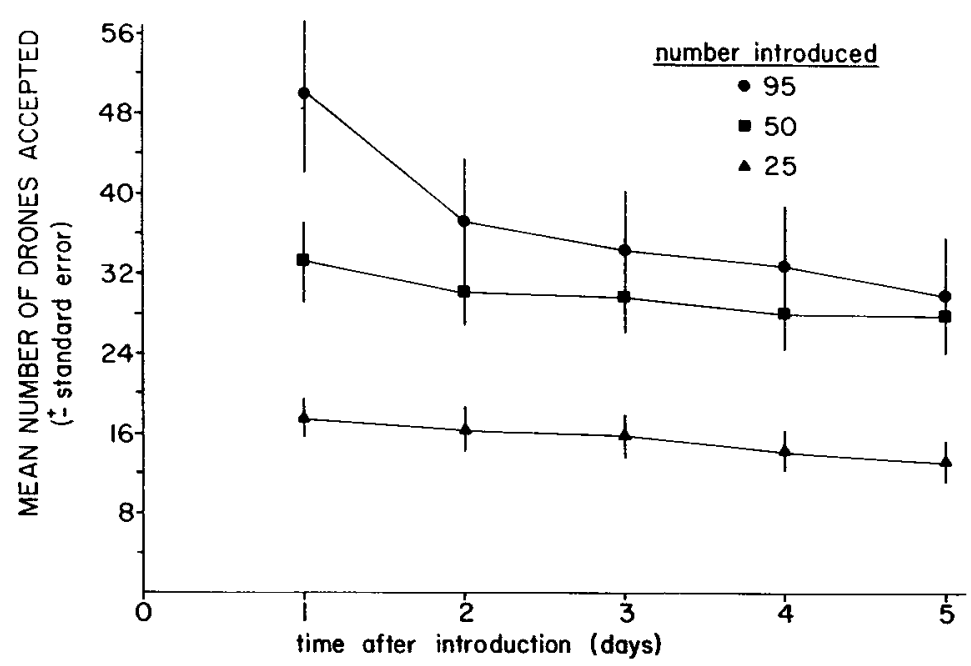

FIG. 3. - Mean number of drones accepted in colonies during the first five days after 25, 50 and 95 drones were introduced.

\section{DISCUSSION}

The number of drones found in a colony is positively correlated with colony size (FrEE, 1957). The number of adult drones in a colony is regulated partly by the workers which are known to evict drones in the fall and under periods of nectar dearth (RibBands, 1953 ; LEVENETS, 1956 ; RUTTNER, 1956 ; 
WeIss, 1962). Colonies will accept foreign drones that are introduced into them and drones that drift from other colonies (CuRRIE and JAY, 1988). However, colonies appear to limit the number of foreign drones that were accepted (Fig. 3). In our study, « optimal » acceptance was obtained when 50 drones were introduced into single story hives (Fig. 7). The number of foreign drones a colony will accept, however, may vary with different stocks and different environmental conditions. CuRRIE and JAY (1988) found that very high acceptance of drones could be achieved ( $87 \%$ after 5 days) when 100 drones were introduced into single story hives, if environmental conditions were favorable. The optimal number of drones to introduce into colonies in order to maximize acceptance probably also varies with factors that influence worker tolerance of drones and the number of drones found in the colony e.g., the amount of forage, the queen state, and the colony size (FrEE and Williams, 1975).

Acceptance was higher when queen excluders were used to confine the drones within the colony for a period of about 18 hours, than when no excluders were used (Fig. 1 and 2). It has been shown that guard bees recognize foreign intruders partly by their odor (Kalmus and RibBands, 1952). The queen excluders may have allowed the drones time to acquire the colony odors, which would result in fewer drones being evicted by the worker bees.

The use of excluders may also have prevented drones from leaving the colony. When drones are introduced into colonies they often walk out of the hive entrance towards the sun when it is low on the horizon, although none seem to be attacked or mauled by workers before leaving (JAY and CuRRIE pers. obs.). Young drones exhibit a strong positive phototaxis (BERTHOLd and BEnTon, 1970). When queen excluders were not used the acceptance was highest in the evening (Fig. 1), probably because few drones walked out of the hive as a result of their attraction to light.

Acceptance was significantly lower when drones were held overnight and introduced into colonies on the following morning. This may have been due, in part, to a weakening of the drones, death of some of the drones during the time that the drones had to be stored, or because the drones were confined in the colony for a shorter period (queen excluders were removed before the next period of drone flight began). Therefore, retaining marked drones overnight for introduction on the following day does not increase acceptance.

FREE (1957) has suggested that primarily « unemployed foragers » attack drones and evict them from a colony. This may partly explain why acceptance was higher in the afternoon than in the evening when queen excluders were used (Fig. 1). There may be fewer guard bees to « harass » introduced drones in the afternoon, than in the evening. Environmental factors might affect the 
behavior of workers towards foreign drones which also may affect drone acceptance.

Odors (like vanilla) that mask a bee's odors have been used successfully in increasing the acceptance of introduced queens (e.g. Dixon, 1979) and might also increase the acceptance of introduced drones. Masking of the drone's odors might increase the number of drones that a colony will support, but the effects this could have on drone behavior are not known.

Drones that were either rejected by workers or died as a result of handling and marking could not be evicted from the hive and thus collected on the queen excluder. When the marked drones were introduced no other marked or unmarked drones were found dead on the excluders. Therefore, the introduction of drones into a colony did not appear to affect populations of drones already present in the hive. The excluders also did not appear to increase the number of drones in the colony above the level that a colony would "normally" support because, after the excluders were removed, the rate at which drones were evicted from the colonies with excluders did not differ from in colonies without excluders (Fig. 2).

The results of this study indicate that the number of introduced drones that are accepted by a colony can be increased by confining the drones within the colony, by using queen excluders and by introducing the drones in the afternoon rather than the late evening or on the following morning. However, colonies do appear to limit the number of drones that are accepted, thus acceptance is not always increased by introducing more drones. It may be possible to induce colonies to hold more drones by increasing the number of workers in the colony or by introducing worker and drone bees.

Received for publication in July 1987. Accepted for publication in April 1988.

\section{ACKNOWLEDGMENTS}

We would like to thank Darcie Bielaszka and Daryl Wright for their assistance in marking bees and collecting the data. We would like to thank the National Sciences and Engineering Research Council of Canada and the Manitoba Department of Agriculture for providing funding for this study. 


\title{
RÉSUMÉ \\ FACTEURS INFLUENÇANT L'ACCEPTATION DE MÂLES ÉTRANGERS DANS DES COLONIES D'ABEILLES
}

Des études sur la gestion des mâles pourraient contribuer, dans les programmes de sélection de l'abeille, à améliorer l'efficacité et la qualité de l'accouplement. On a étudié dans ce travail l'action de l'introduction de mâles étrangers dans des colonies d'abeilles. Les objectifs étaient de savoir si les colonies limitaient l'acceptation des mâles étrangers et d'en augmenter le nombre.

On a introduit des mâles étrangers dans des colonies à une hausse, suivant deux techniques différentes, selon que les mâles étaient confinés à l'intérieur de la ruche (méthode avec grille) ou non (méthode sans grille). Pour chaque technique, les mâles étaient introduits l'après-midi, le soir ou le lendemain matin. Dans la méthode sans grille, on plaçait un grillage de $8 \mathrm{~mm}$ de maille entre le nid à couvain et la hausse vide; on lâchait les mâles sur le grillage, enfumait légèrement les abeilles et replaçait le couvercle sur la hausse. La technique avec grille différait de la précédente par la pose d'une grille à reines entre le corps de ruche et le plancher. Les grillages étaient mis à chaque introduction et les grilles à reines enlevées avant que ne débute la période suivante de vol des mâles.

L'expérience a été reproduite 10 fois. Au sein d'un mème essai, le même nombre de mâles a été introduit dans chaque ruche, mais il a varié d'un essai à l'autre. On examinait toutes les ruches le matin de bonne heure avant que les vols de mâles ne commencent et le nombre de mâles acceptés dans chaque ruche était enregistré pendant les 5 jours suivant l'introduction.

Le nombre de mâles acceptés est significativement plus élevé quand les mâles marqués sont confinés dans la colonic toute la nuit à l'aide d'une grille à reine $(\mathrm{P}<0,003)$ (Fig. 2). Il existe une corrélation significative entre la technique d'introduction utilisée et la période de la journée durant laquelle a lieu l'introduction ( $\mathrm{P}<0,001)$ (Fig. 1). Quand les mâles introduits sont confinés dans la ruche avec une grille à reines, l'acceptation est plus élevéc s'ils sont introduits l'après-midi plutôt que le soir ou le lendemain matin. Néanmoins quand les mâles ne sont pas confinés dans la ruche (i.e. quand il n'y a pas de grille à reines), l'acceptation est plus élevéc si l'introduction a lieu le soir.

Les colonies semblent limiter le nombre de mâles acceptés. Il n'y a pas de différence significative du nombre de mâles acceptés au bout de 5 jours, que l'on en introduise 50 ou 95 (Fig. 3). Néanmoins l'acceptation après 5 jours est significativement plus élevée si l'on en introduit 50 ou plus, que si 25 seulement sont introduits. On en conclut donc que le nombre de mâles acceptés par une colonie peut être accru en confinant ceux-ci dans la colonie pendant $18 \mathrm{~h}$ environ après l'introduction et en les introduisant l'après-midi. Mais au-delà de 50 mâles introduits par ruche, le nombre de mâles acceptés ne peut être augmenté.

\section{ZUSAMMENFASSUNG}

\author{
FAKTOREN DER ANNAHME VON FREMDEN DROHNEN \\ DURCH VÖLKER DER HONIGBIENE (APIS MELLIFERA L.)
}

Untersuchungen über die Drohnenhaltung können in Zuchtprogrammen der Honigbiene zur Verbesserung der Effektivität und Qualität der Begattung beitragen. In der vorliegenden Studie wurde der Effekt der Zugabe fremder Drohnen zu Bienenvölkern untersucht. Es sollte festgestellt werden, ob die Völker die Anzahl an akzeptierten Drohnen limitieren und ob die Anzahl an akzeptierten, markierten Drohnen erhöht werden kann.

Die Drohnen wurden den (1-zargigen) Völkern auf zwei verschiedene Weisen zugegeben : 
- bei der "no-excluder Technik" wurden sie nach dem Einsetzen in die Völker nicht im Kasten zurückgehalten halten.

- bei der «excluder Technik» wurden sie nach dem Einsetzen in die Völker im Kasten zurückge-

Bei beiden Methoden wurden die Drohnen am Nachmittag, am Abend und am folgenden Morgen zugesetzt. Dazu wurde ein Drahtgitter mit $8 \mathrm{~mm}^{2}$ Maschenweite zwischen Brutraum und einer leeren Zarge eingelegt. Die markierten Drohnen wurden dann auf das Gitter gesetzt, die Bienen leicht beraucht und der Deckel wieder auf die leere Zarge aufgelegt. Die excluder Technik unterschied sich von der noexcluder Technik dadurch, daß ein Königinnenabsperrgitter zwischen Zarge und Unterboden eingelegt wurde. Die Absperrgitter wurden zum Zeitpunkt der Drohnenzugabe eingesetzt und - bevor die nächste Drohnenflugperiode begann - wieder entfernt.

Jedes Experiment wurde $10 \mathrm{mal}$ wiederholt. Bei jedem Test wurden gleiche Anzahlen an Drohnen in die Völker eingebracht; zwischen den Tests variierte die Anzahl. Alle Völker wurden frühmorgens (vor dem Drohnenflug) durchgesehen und die Anzahl der akzeptierten Drohnen nach dem Einsetzen fünf Tage protokolliert.

Die Anzahl der akzeptierten Drohnen war signifikant $(\mathrm{p}<0.003)$ größer, wenn die markierten Drohnen über Nacht hinter den Königinnenabsperrgittern in der Kolonie gefangengehalten wurden (Fig. 2). Es gab einen signifikanten Zusammenhang zwischen der verwendeten Zugabemethode und der Tageszeit zu der die Drohnen zugegeben wurden $(\mathrm{p}<0.001)$ (Fig. 1). Bei der excluder Methode war die Akzeptanz größer, wenn die Drohnen nachmittags zugegeben wurden als am Abend oder am folgenden Morgen. Bei der no-excluder Technik war die Akzeptanz am Abend am größten.

Die Völker schienen die Anzahl an akzeptierten Drohnen zu limitieren. Wenn 50 oder 95 Drohnen zugegeben wurden, war die mittlere Anzahl an akzeptierten Drohnen nach fünf Tagen nicht signifikant verschieden (Fig. 3). Jedoch war die Akzeptanz bei Zugabe von 50 oder mehr Drohnen nach 5 Tagen signifikant höher als bei Zugabe von nur 25 Drohnen. Daraus wurde geschlossen, daß die Anzahl der durch ein Volk akzeptierten Drohnen erhöht werden kann, indem man die Drohnen nachmittags zugibt und in dem Volk für mindestens 18 Stunden zurückhält. Jedoch wurde die Anzahl der akzeptierten Drohnen nich erhöht, wenn man mehr als 50 Drohnen pro Volk zusetzte.

\section{REFERENCES}

Berthold R., Benton A.W., 1970. - Honeybee photoresponse as influenced by age. Part II : Drones and Queens. Ann. Entomol. Soc. Am., 63, 1113-1116.

CuRrie R.W., 1982. - Some factors affecting the orientation of drone honey bees. University of Manitoba, M. Sc. Thesis.

Currie R.W., 1987. - The biology and behaviour of drones. Bee World, 68, 129-143.

CURRIE R.W., JAY S.C., 1988. - The influence of a colony's queen state, the time of year, and drifting behaviour, on the acceptance and longevity of adult drone honeybees (Apis mellifera L.). J. Apic. Res. (in press).

Dixon D.P., 1979. - Factors affecting the production of honeybee queens (Apis mellifera L.). University of Manitoba, M. Sc. Thesis.

Free J.B., 1957. - The food of adult drone honeybees (Apis mellifera). Brit. J. Anim. Behav, 5, 7-11.

FREE J.B. and Williams I.H., 1975. - Factors determining the rearing and rejection of drones by the honeybee colony. Anim. Behav, 23, 650-675.

HARris L., 1979. - A rapid method for colour-marking single honeybees with fluorescent paint. J. Apic. Res., 18, 201-203. 
J AY S.C., 1969. - Studies on hiving package bees. I. Effects of various factors on loss and drifting of bees. J. Apic. Res., 8, 83-89.

Kalmus H., Ribbands C.R., 1952. - The origin of the odours by which honeybees distinguish their companions. Proc. R. Soc. London B, 40, 50-59.

LeVenets I.P., 1956. - [Observations on the expulsion of drones.] Pchelovodstvo, 33, 28-29 (in Russian).

Nelson D.L., 1985. - The effect of apiary relocation on the orientation of honey bees. University of Manitoba. Ph. D. Thesis.

Ribbands C.R., 1953. - The behaviour and social life of honeybees. Hale Publishing Co., Hapeville Georgia, U.S.A.

Rowell A., TAYlor O.R., LockE S.J., 1986. - Variation in drone mating flight times among commercial honey bee stocks.

RuttNer R., 1956. - The mating of the honeybee. Bee World, 37, 3-15.

Snedecor G.W., Cochran W.G., 1980. - Statistical Methods. The Iowa State University Press. Ames, Iowa, U.S.A.

WeISS K., 1962. - [Investigations on drone production in the colony.] Arch Bienenkd., 39, 1-7 (in German).

Witherell P.C., 1972. - Flight activity and natural mortality of normal and mutant drone honeybees. $J$. Apic. Res., 11, 65-75. 